Article

\title{
Supplementation of Probiotic Butyricicoccus pullicaecorum Mediates Anticancer Effect on Bladder Urothelial Cells by Regulating Butyrate-Responsive Molecular Signatures
}

\author{
Yen-Chieh Wang ${ }^{1,2}$, Wei-Chi Ku ${ }^{2}$, Chih-Yi Liu ${ }^{2,3}{ }^{(D)}$, Yu-Che Cheng ${ }^{2,4,5}$, Chih-Cheng Chien ${ }^{2,6}$, \\ Kang-Wei Chang 7,8 (1) and Chi-Jung Huang ${ }^{4,9, *}$
}

1 Department of Urology, Cathay General Hospital, Taipei 106438, Taiwan; litiger.wang@msa.hinet.net

2 School of Medicine, College of Medicine, Fu Jen Catholic University, New Taipei 242062, Taiwan; 089052@mail.fju.edu.tw (W.-C.K.); cyl1124@gmail.com (C.-Y.L.); yccheng@cgh.org.tw (Y.-C.C.); chienc@cgh.org.tw (C.-C.C.)

3 Department of Pathology, Sijhih Cathay General Hospital, New Taipei 221037, Taiwan

4 Department of Medical Research, Cathay General Hospital, Taipei 106438, Taiwan

5 Department of Biomedical Sciences and Engineering, National Central University, Taoyuan 320317, Taiwan

6 Department of Anesthesiology, Cathay General Hospital, Taipei 106438, Taiwan

7 Taipei Neuroscience Institute, Taipei Medical University, Taipei 110301, Taiwan; kwchang@tmu.edu.tw

8 Laboratory Animal Center, Taipei Medical University, Taipei 110301, Taiwan

9 Department of Biochemistry, National Defense Medical Center, Taipei 114201, Taiwan

check for

updates

Citation: Wang, Y.-C.; Ku, W.-C.; Liu, C.-Y.; Cheng, Y.-C.; Chien, C.-C.; Chang, K.-W.; Huang, C.-J. Supplementation of Probiotic Butyricicoccus pullicaecorum Mediates Anticancer Effect on Bladder Urothelial Cells by Regulating Butyrate-Responsive Molecular Signatures. Diagnostics 2021, 11, 2270. https://doi.org/10.3390/ diagnostics 11122270

Academic Editor: Massimo Moro

Received: 28 September 2021

Accepted: 2 December 2021

Published: 4 December 2021

Publisher's Note: MDPI stays neutral with regard to jurisdictional claims in published maps and institutional affiliations.

Copyright: (c) 2021 by the authors. Licensee MDPI, Basel, Switzerland. This article is an open access article distributed under the terms and conditions of the Creative Commons Attribution (CC BY) license (https:// creativecommons.org/licenses/by/ $4.0 /)$.
* Correspondence: aaronhuang@cgh.org.tw

Abstract: In bladder cancer, urothelial carcinoma is the most common histologic subtype, accounting for more than $90 \%$ of cases. Pathogenic effects due to the dysbiosis of gut microbiota are localized not only in the colon, but also in regulating bladder cancer distally. Butyrate, a short-chain fatty acid produced by gut microbial metabolism, is mainly studied in colon diseases. Therefore, the resolution of the anti-cancer effects of butyrate-producing microbes on bladder urothelial cells and knowledge of the butyrate-responsive molecules must have clinical significance. Here, we demonstrate a correlation between urothelial cancer of the bladder and Butyricicoccus pullicaecorum. This butyrate-producing microbe or their metabolite, butyrate, mediated anti-cancer effects on bladder urothelial cells by regulating cell cycle, cell growth, apoptosis, and gene expression. For example, a tumor suppressor against urothelial cancer of the bladder, bladder cancer-associated protein, was induced in butyratetreated HT1376 cells, a human urinary bladder cancer cell line. In conclusion, urothelial cancer of the bladder is a significant health problem. To improve the health of bladder urothelial cells, supplementation of B. pullicaecorum may be necessary and can further regulate butyrate-responsive molecular signatures.

Keywords: urothelial bladder cancer; butyrate; Butyricicoccus pullicaecorum; apoptosis; bladder cancer-associated protein

\section{Introduction}

The burden of urologic cancer is increasing globally because of population aging [1]. In addition to prostate cancer, other urologic cancers such as bladder cancer and kidney cancer remain common malignancies worldwide [2]. Among these urinary system tumors, urothelial carcinoma displays distinct histomorphological phenotypes [3,4] and is likely to arise from different uroprogenitor cells [5]. Genomic characterization of bladder cancer may provide new insights into understanding the nature of this complex disease, leading to the development of effective therapies $[3,5]$.

The microbiota isolated from the urine of patients with bladder cancer have been associated with bladder tumors [6-8]. Some of these urine-derived bacteria may potentially become biomarkers or therapeutic targets for bladder cancer $[9,10]$. Most microbiota are located within the colonic tract, where they play a clinically significant role 
in human health and the development of disease. However, the effects of gut microbiota are also found on other organs, where they exert pathogenic effects as a result of dysbiosis [11-14]. Dysbiosis of bacteria in the colon is thought to be involved in regulating bladder cancer $[15,16]$. Some ongoing clinical trials have focused on the signatures of gut microbiota as markers of the efficacy of immune-checkpoint immunotherapy in bladder cancers [17]. Short-chain fatty acids (SCFAs), a group of metabolites from gut microbiota, have been known to play a crucial role in improving human health for many years [18]. For example, one SCFA, butyrate, synthesized from dietary carbohydrates by bacterial fermentation in the colon $[15,19]$, may be a potent proliferation inhibitor of urothelial cancer of the bladder $[15,20]$. In this context, butyrate-induced growth inhibition is potentially clinically significant [20]. In addition, butyrate may influence the expression of tumor suppressors involved in chemotherapy treatment, affecting the pathological outcome of some bladder cancers [21]. Therefore, a better understanding of the role of butyrate-producing microbes and the correlation between butyrate and tumor suppressors in the development and progression of bladder cancer would be helpful for exploring new therapeutic options.

In fact, a safe butyrate-producing microbe, Butyricicoccus pullicaecorum, has been shown in clinical trials to possibly reduce cancer progression $[22,23]$. In the present research, we aimed to demonstrate the anticancer effect of B. pullicaecorum on the induction of antitumor molecular events by determining the molecular effects of butyrate on urothelial cancer of the bladder and evaluating cell cycle regulation and apoptosis in the cells of bladder urothelial cancer in the presence of butyrate. Our results suggest that the major metabolite of butyrate-producing microbes in the colon (butyrate) is an important factor in impairing the development of bladder cancer. Supplementation of B. pullicaecorum may provide opportunities for therapeutic intervention in different bladder cancers through the secretion of the specific SCFA, butyrate.

\section{Materials and Methods}

\subsection{Mouse with B. pullicaecorum Administration}

$\mathrm{C} 3 \mathrm{H} / \mathrm{He}$ mice (male) aged 4-6 weeks were provided by the National Laboratory Animal Center, NARLabs, Taiwan. All protocols were approved by the Institutional Animal Care and Use Committees at Cathay General Hospital (Taipei, Taiwan). All efforts were made to minimize the number of animals and their suffering. Three to five mice were housed per plastic cage under pathogen-free conditions (humidity: $50 \% \pm 10 \%$; light: $12 / 12 \mathrm{~h}$ light/dark cycle; temperature: $23{ }^{\circ} \mathrm{C} \pm 2{ }^{\circ} \mathrm{C}$ ) in an individually ventilated cage rack system (Tecniplast, Varese, Italy). Mice were randomly divided into two groups for testing B. pullicaecorum: (1) control subgroup $(n=4)$ and (2) subgroup with B. pullicaecorum $\left(1 \times 10^{7} \mathrm{CFU}\right.$ in $\left.100 \mu \mathrm{L}\right)$ administration through anal injection $(n=4)$, as illustrated in Supplementary Materials Figure S1. B. pullicaecorum (BCRC-81109) was purchased from the Bioresource Collection and Research Center (Hsinchu, Taiwan) and grown in BCRC medium 967 for 3 days in anaerobic conditions at $37^{\circ} \mathrm{C}$. The efficacy of B. pullicaecorum administration was acquired by specific quantitative real-time PCR (Supplementary Materials Figure S2).

\subsection{Urinary Bladder Cells and Sodium Butyrate Treatment}

Human urinary bladder cancer cell line HT1376 (ATCC CRL-1472) was purchased from American Type Culture Collection (ATCC; Manassas, VA, USA). This cell line was expanded in a complete medium (Eagle's Minimum Essential Medium with $10 \%$ fetal bovine serum) under $95 \%$ air atmosphere (with $\mathrm{CO}_{2}$ ) in a $37^{\circ} \mathrm{C}$ humidified incubator. To evaluate the effects of butyrate on $\mathrm{HT} 1376$ cells, the $50 \%$ inhibitory concentration $\left(\mathrm{IC}_{50}\right)$ of sodium butyrate $(\mathrm{NaB})$ was used to treat cells for $72 \mathrm{~h}$.

\subsection{Immunohistochemical Staining}

For immunohistochemical staining to detect various proteins, a VECTASTAIN Elite ABC kit (Cat No. PK-6101; Vector Laboratories, Burlingame, CA, USA) was used according 
to the manufacturer's instructions. Briefly, after deparaffinization, sections were rehydrated sequentially with $100 \%, 90 \%$, and $70 \%$ ethanol. These rehydrated slides were immersed in a citrate buffer $(10 \mathrm{mM}, \mathrm{pH} 6.0)$, boiled $\left(95-99{ }^{\circ} \mathrm{C}\right)$ for $20 \mathrm{~min}$ and then cooled to $25^{\circ} \mathrm{C}$ for $20 \mathrm{~min}$. To inactivate endogenous peroxidases and block potential nonspecific binding sites, tissue sections were incubated for $30 \mathrm{~min}$ in a $3 \% \mathrm{H}_{2} \mathrm{O}_{2}$ methanolic solution and then blocked for a further 30 min with a blocking serum solution (Vector Laboratories). Target protein was, respectively immune-detected with anti-GPR43 antibody (1:50 in blocking solution; Cat No. BS-13536R; Bioss, Boston, MA, USA), anti-GPR109B antibody (1:500 in blocking solution; Cat No. ABP-56889; Abbkine, Wuhan, China), anti-BLCAP antibody (1:10 in blocking solution; Cat No. PA5-38639; Thermo Fisher Scientific, Waltham, MA, USA), and anti-FABP4 antibody (1:25 in blocking solution; Cat No. 15872-1-AP; Proteintech, Rosemont, IL, USA) for $16 \mathrm{~h}$ at $4{ }^{\circ} \mathrm{C}$. After several washes in Tris-buffered saline, tissue sections were incubated with biotinylated goat anti-rabbit IgG antibody (1:200 in blocking solution; cat no. BA-1000; Vector Laboratories) for $0.5 \mathrm{~h}$ at $25^{\circ} \mathrm{C}$. Finally, all target proteins were visualized using the DAB Substrate Kit (Cat No. SK-4100; Vector Laboratories) as the substrate. Hematoxylin was used to stain the nucleus, and the results were analyzed by pathologists.

\subsection{Change in Growth of HT1376 Cells following NaB Treatment}

The growth of HT1376 cells was evaluated using an MTT assay (Cat. No. M5655; Merck KGaA). First, HT1376 cells were cultured at $1 \times 10^{4}$ cells/well in 96-well flatbottom plates for $24 \mathrm{~h}$ and the $\mathrm{IC}_{50}$ of $\mathrm{NaB}$ was determined by treating cells at different concentrations $(0.05,0.5,5,50,100$, and $200 \mathrm{mM})$ for $72 \mathrm{~h}$. To evaluate the efficiency of adjuvant therapy, HT1376 cells $\left(5 \times 10^{3}\right.$ cells/well $)$ were treated with a combined medium (the complete medium for cell culture and a certain percentage of the conditioned medium for B. pullicaecorum cultivation) for 3 or 6 days, and cell viability was calculated using an MTT assay. Briefly, the cells were treated with $10 \mu \mathrm{L}$ of the MTT reagent and incubated in the dark for $4 \mathrm{~h}$. Dimethyl sulfoxide $(100 \mu \mathrm{L})$ was subsequently added to dissolve the purple precipitate formed by the viable cells. The absorbance of each well at $540 \mathrm{~nm}$ was read by a Synergy HT Multi-Mode microplate reader (BioTek Instruments). A $0.22 \mu \mathrm{m}$ membrane filter (Cat No. GSWP04700; Merck KGaA) was used for sterilizing filtration before use. Data were obtained from three independent experiments.

For the bromodeoxyuridine (BrdU) incorporation experiment, HT1376 cells were treated with the predetermined $\mathrm{IC}_{50}$ of $\mathrm{NaB}$ and cultured for $72 \mathrm{~h}$. Cells were then processed for BrdU incorporation using a BrdU cell proliferation assay Kit (Cat. No. K306-200; Biovision, Milpitas, CA, USA) according to the manufacturer's protocol. Plates were read immediately after the addition of stop solution at $450 \mathrm{~nm}$ in triplicate in a Synergy HT Multi-Mode microplate reader (BioTek Instruments).

\subsection{Quantitative PCR}

Total RNA of HT1376 cells with the predetermined $\mathrm{IC}_{50}$ of $\mathrm{NaB}$ for $72 \mathrm{~h}$ was extracted using RNAzol RT (Molecular Research Center) and converted to cDNA with a HighCapacity cDNA Reverse Transcription Kit in the presence of oligo(dT) primers (Thermo Fisher Scientific) according to the manufacturer's instructions. To quantify the expression of GPR43 and GPR109B, the reaction mixture containing the cDNA sample, QuantiTect SYBRGreen PCR Master mix (Qiagen GmbH), QuantiTect Primer assay (Cat No. Hs_FFAR2_1_SG for GPR43 and Cat No. Hs_HCAR3_1_SG for GPR109B; Qiagen GmbH), and RNase-free water was amplified using the following cycling program: $10 \mathrm{~min}$ at $95{ }^{\circ} \mathrm{C}$ followed by 40 cycles at $95^{\circ} \mathrm{C}$ for $15 \mathrm{~s}$ and at $60{ }^{\circ} \mathrm{C}$ for $1 \mathrm{~min}$. TaqMan Gene Expression Assays were applied by commercially available primer sets (FasL, Cat No. Hs00181225_m1; Thermo Fisher Scientific) or universal probe sets (FABP4, BLCAP, and CDK1; primer sequences and universal probe number in Table 1; Roche Diagnostics GmbH). LightCycler TaqMan Master (Roche Diagnostics $\mathrm{GmbH}$ ) and RNase-free water was amplified by a program (10 min at $95^{\circ} \mathrm{C}$, proceeding with 60 cycles at $95^{\circ} \mathrm{C}$ for $10 \mathrm{~s}$ and at $60^{\circ} \mathrm{C}$ for $20 \mathrm{~s}$ ). All mRNA levels 
were adjusted relative to the level of glyceraldehyde-3-phosphate dehydrogenase (Table 1) and all quantitative PCR reactions were run in a LightCycler 96 (Roche Diagnostics $\mathrm{GmbH}$ ) and the data were analyzed using the $2-\Delta \Delta \mathrm{Cq}$ method [24].

Table 1. Primer sequences and probe numbers for real-time PCR.

\begin{tabular}{|c|c|c|c|}
\hline Gene Name & Accession Number & Sequence (From $5^{\prime}$ to $\left.3^{\prime}\right)$ & UPL Number \\
\hline FABP4 & NM_001442 & $\begin{array}{l}\text { F: CCACCATAAAGAGAAAACGAGAG } \\
\text { R: GTGGAAGTGACGCCTTTCAT }\end{array}$ & \#31 \\
\hline BLCAP & NM_006698 & $\begin{array}{l}\text { F: CGCCATGGTTCCAAGAAT } \\
\text { R: CGCTTTCTTCAACCCTCACT }\end{array}$ & $\# 17$ \\
\hline CDK1 & NM_001786 & $\begin{array}{l}\text { F: TGGATCTGAAGAAATACTTGGATTCTA } \\
\text { R: CAATCCCCTGTAGGATTTGG }\end{array}$ & \#79 \\
\hline GAPDH & NM_002046 & $\begin{array}{l}\text { F: CTCTGCTCCTCCTGTTCGAC } \\
\text { R: ACGACCAAATCCGTTGACTC }\end{array}$ & $\# 60$ \\
\hline
\end{tabular}

ABP4, fatty acid binding protein 4; BLCAP, bladder cancer associated protein; CDK1, cyclin dependent kinase 1; GAPDH, glyceraldehyde-3phosphate dehydrogenase; F, forward primer; R, reverse primer; UPL, Universal ProbeLibrary from Roche Diagnostics GmbH (Germany).

\subsection{Analyses of Cell Cycle and Apoptosis through Image Cytometry}

The cell cycle and apoptosis analyses of HT1376 cells were performed using a fluorescence image cytometer (NucleoCounter NC-3000; ChemoMetec A/S, Denmark) [25,26]. HT1376 cells were seeded in a six-well dish at a density of $3.6 \times 10^{5}$ cells per well and treated with the predetermined $\mathrm{IC}_{50}$ of $\mathrm{NaB}$ for $72 \mathrm{~h}$ after a $16 \mathrm{~h}$ pre-incubation period.

For cell cycle analysis, cells were harvested by trypsinization, suspended in $0.5 \mathrm{~mL}$ of phosphate-buffered saline (PBS) and fixed with $4.5 \mathrm{~mL}$ of $70 \%$ cold ethanol for at least $2 \mathrm{~h}$. Subsequently, the ethanol was removed and the cells were resuspended in PBS. Cell pellets were harvested by centrifugation at $500 \times g$ for $5 \mathrm{~min}$ at $4{ }^{\circ} \mathrm{C}$ and incubated with $0.5 \mathrm{~mL}$ DAPI solution (0.1\% Triton X-100 and $4^{\prime}, 6$-diamidino-2-phenylindole) for $5 \mathrm{~min}$ at $37^{\circ} \mathrm{C}$. The stained cells were loaded into an NC-Slide A8 (ChemoMetec) and evaluated using a Fixed Cell Cycle-DAPI/DNA fragmentation assay protocol in the NucleoCounter NC-3000 image cytometer (ChemoMetec) [27]. The acquired DNA content histograms were used to distinguish cells at different phases (G1, S, and G2/M) of the cell cycle with NucleoView NC-3000 software (version 2.1.25.12; ChemoMetec).

For the apoptosis analysis, cells were harvested by trypsinization and suspended in $0.1 \mathrm{~mL}$ of annexin $\mathrm{V}$ binding buffer with $2 \mu \mathrm{L}$ of FITC-labeled annexin $\mathrm{V}$ and $2 \mu \mathrm{L}$ of Hoechst33342 $(500 \mu \mathrm{g} / \mathrm{mL})$. The cells were then incubated for $15 \mathrm{~min}$ at $37^{\circ} \mathrm{C}$ and subsequently centrifuged at $400 \times g$ for $5 \mathrm{~min}$. Following the removal of the supernatant, the cell pellets were resuspended in $300 \mu \mathrm{L}$ of annexin $\mathrm{V}$ binding buffer and centrifuged twice under the conditions described above. The cell pellets were resuspended in $100 \mu \mathrm{L}$ of annexin $\mathrm{V}$ binding buffer, and $2 \mu \mathrm{L}$ of propidium iodide $(500 \mu \mathrm{g} / \mathrm{mL})$ was added. Eventually, the prepared samples were loaded immediately into NC-Slide A2 (ChemoMetec) and analyzed using the annexin $\mathrm{V}$ assay protocol in the NucleoCounter NC-3000 image cytometer (ChemoMetec) [28]. The obtained scatterplots were used to demarcate the percentage of healthy cells and early and late apoptotic cells, respectively.

Western blots to detect FasL protein from HT1376 cells without or with $2.4 \mathrm{mM}$ $\mathrm{NaB}$ treatment for $72 \mathrm{~h}$ were performed followngi standard procedure and the antibodies specific to target proteins were based on our previous report with minor modifications: anti-FasL, 1:20, \#ab15285 (Abcam, Cambridge, UK); anti-glyceraldehydes-3-phosphate dehydrogenase, 1:4000, \#AM4300 (Thermo Fisher Scientific) [29]. The secondary antibody, either anti-rabbit or anti-mouse, which was conjugated with alkaline phosphatase, was then used. Blots were finally developed using VECTASTAIN ABC-AmP DuoLuX chemiluminescent/fluorescent substrate kits for alkaline phosphatase (SK-6005; Vector Laboratories, Burlingame, CA, USA) according to the manufacturer's instructions. The images of immunoblots were captured on a FluorChem FC2 system (Cell Biosciences, Santa Clara, CA, USA). 


\subsection{Statistical Analysis}

Student's $t$-test was used to determine the mean differences between treatment and control, and values of $p<0.05$ were considered statistically significant. Data are presented as mean $\pm \mathrm{SEM}$.

\section{Results}

3.1. In Vivo Evaluation of SCFA-Related Gene Expression in Mouse Bladder after B. pullicaecorum Administration

Reduction of intestinal microbial metabolite butyrate due to gut microbiota imbalance was believed to be related to colorectal cancer (CRC) development [30]. We also reported that gut microbe B. pullicaecorum could regulate the SCFA transporter and receptor to reduce CRC progression [23]. Thus, we determined the protein level of different SCFArelated genes in mouse bladder urothelial cells after B. pullicaecorum administration, which increased the level of B. pullicaecorum in stools (Supplementary Materials Figure S2). From immunohistochemistry, the predominant dense-intensity staining was seen in transitional epithelium and some positive signals in the lamina propria of GPR43 (Figure 1A), GPR109B (Figure 1B), and FABP4 (Figure 1C). In addition, as illustrated in Figure 1, GPR43, GPR109B, and FABP4 staining existed broadly and evenly in the transitional epithelium of the urinary bladder of mice with this B. pullicaecorum supplementation. By contrast, weak signals of these SCFA-related proteins were locally detected from the bladder urothelial cells of mice when mice were not administered B. pullicaecorum.

\subsection{Upregulation of Butyrate-Responsive Genes in Urothelial Cancer Cells of the Bladder after $\mathrm{NaB}$ Treatment}

We then used bladder urothelial cancer cell line HT1376 to elaborate the effects of NaB on changes of butyrate-responsive molecular signatures. We initially performed the MTT assay to calculate the total cell numbers following the dose dependence and acquired the $\mathrm{IC}_{50}$ after $72 \mathrm{~h} \mathrm{NaB}$ exposure. An $\mathrm{IC}_{50}$ value of about $2.4 \mathrm{mM}$ against HT1376 cells was observed (Figure 2A). The mRNA levels of two G protein-coupled receptors, i.e., GPR43 (11.4-fold) and GPR109B (2.8-fold), were significantly upregulated in HT1376 cells after $\mathrm{NaB}$ treatment at IC50 (Figure 2B: GPR43, $p<0.01$; Figure 2C: GPR109B, $p<0.05$ ) compared with cells without $\mathrm{NaB}$ treatment. Similarly, compared with HT1376 cells not treated with $\mathrm{NaB}$, the NaB-treated HT1376 cells exhibited a higher mRNA level of the fatty acid binding protein, FABP4 (107.7-fold; Figure 2D, $p<0.01)$.

\subsection{Induction of Apoptosis in Bladder Urothelial Cells under a Butyrate-Enriched Microenvironment}

Molecular and cellular functions of butyrate were further studied with in vitro NaBtreated HT1376 cells and in vivo bladder urothelial cells of B. pullicaecorum-supplemented mice. The expression level of the bladder cancer-associated protein (BLCAP), which is an apoptosis-related tumor suppressor identified from bladder cancer [31,32], was significantly higher $(29.2$-fold; $p<0.05)$ in NaB-treated HT1376 cells than that in cells without $\mathrm{NaB}$ treatment (Figure 3A). Moreover, the immunoreactivity of BLCAP was observed in the layer of transitional epithelium of mouse urinary bladder regardless of whether mice had been treated with B. pullicaecorum. Nonetheless, mice with $\mathrm{NaB}$ treatment had stronger immunoreactivity of BLCAP in the transitional epithelium and lamina propria than did control mice, as illustrated in Figure 3B. The improved apoptosis induced by a butyrate-enriched microenvironment could also be found in vitro from the annexin V/PI protocol [33]. As shown in Figure 3C, the percentage of late apoptotic HT1376 cells (annexin $\mathrm{V}$ - and PI-positive cells) increased from $10.7 \%$ to $22.8 \%$ after a $72 \mathrm{~h} \mathrm{NaB}$ incubation period. In addition, we determined the level of Fas Ligand (FasL), one of the molecules involved in the regulation of cell death [34]. We quantified a relatively higher expression of FasL (2.9-fold, $p<0.05$ ) (Figure 3D) and FasL protein level (Figure 3E) from the NaB-treated HT1376 cells compared with non-treated control cells. 
Control

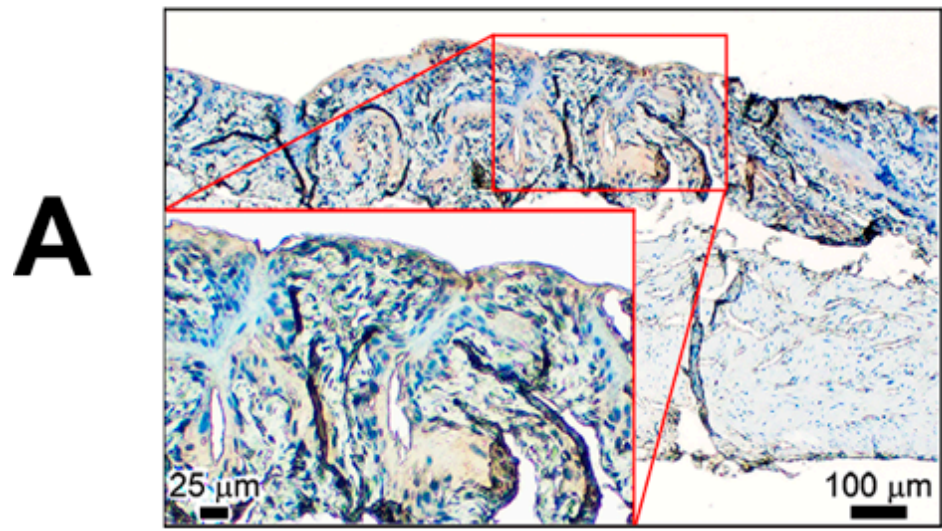

Control

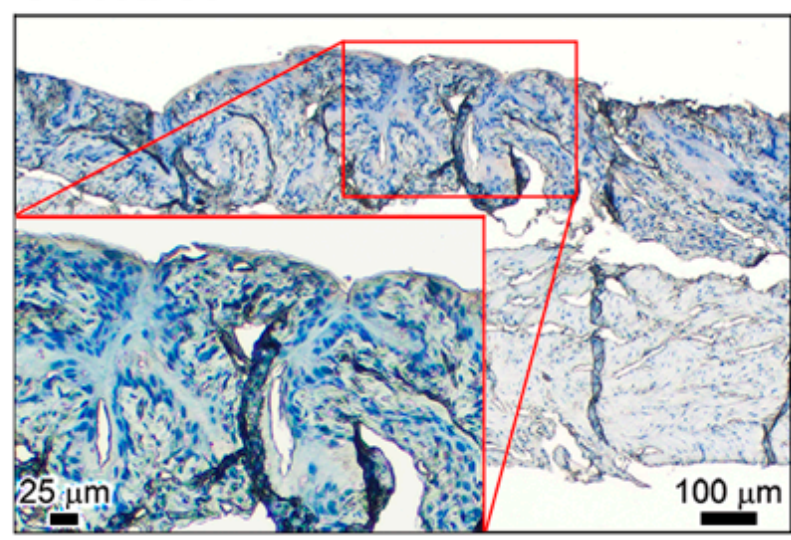

Control

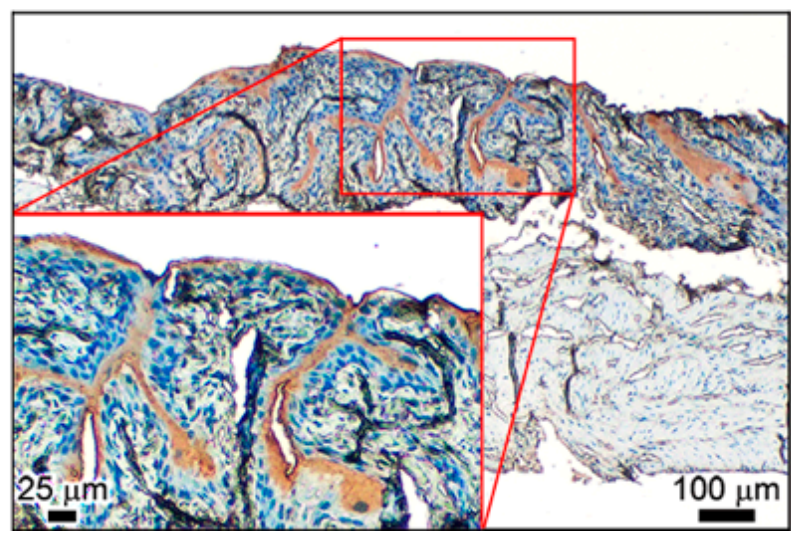

B. pullicaecorum

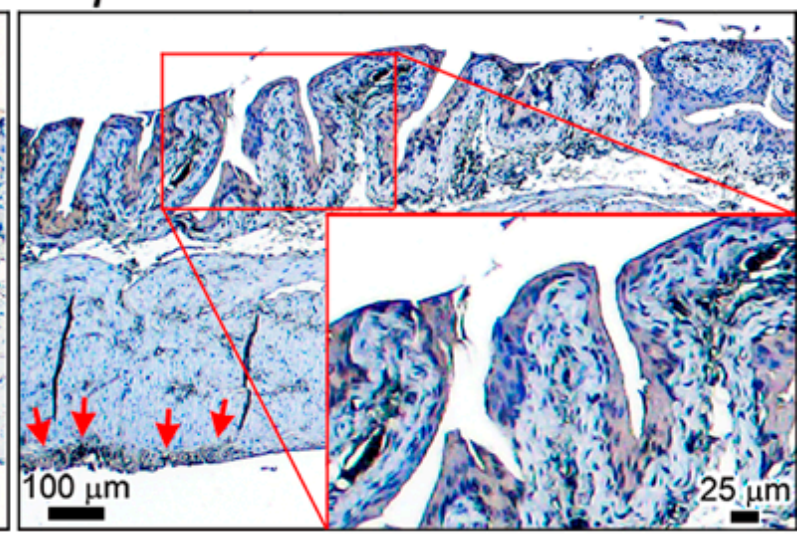

B. pullicaecorum

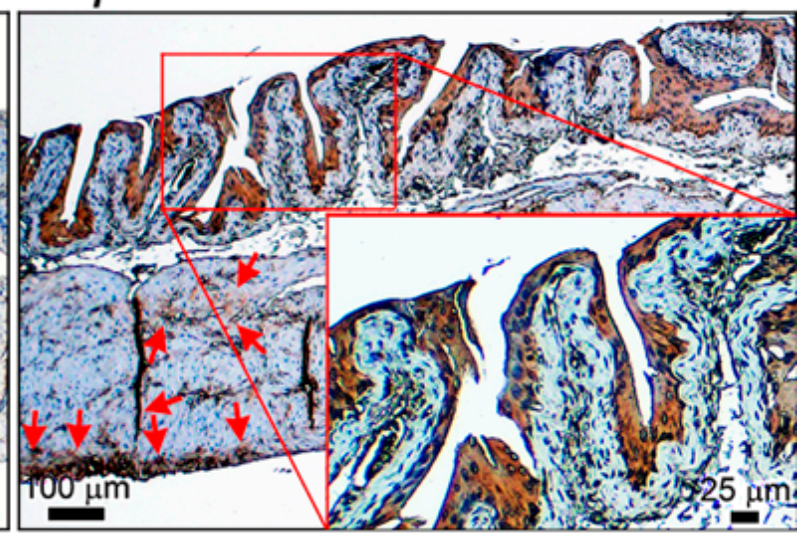

B. pullicaecorum

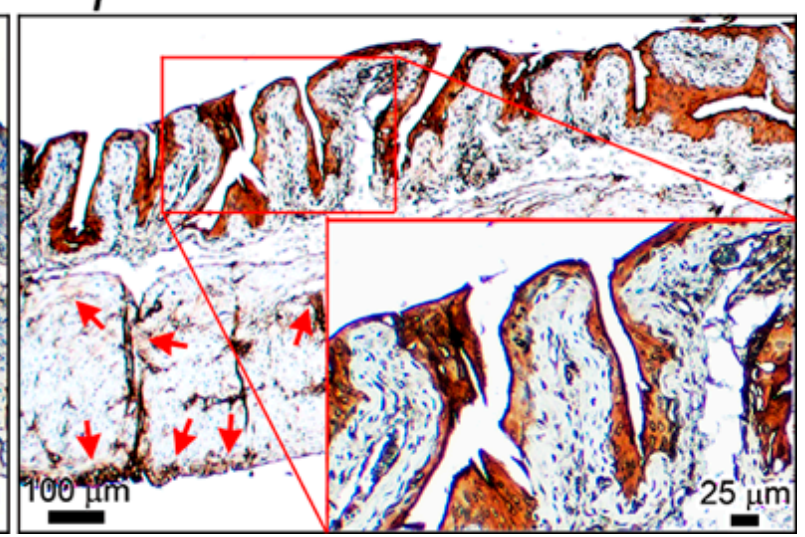

Figure 1. Representative images of SCFA-related gene expression in mouse bladder after B. pullicaecorum administration. (A) GPR43 immunohistochemistry staining. (B) GPR109B immunohistochemistry staining. (C) FABP4 immunohistochemistry staining. Control mice $(n=4)$, without B. pullicaecorum administration; B. pullicaecorum mice $(n=4)$, with $1 \times 10^{7} \mathrm{CFU}$ of B. pullicaecorum administration through anal injection. SCFA, short chain fatty acid.

3.4. NaB-Induced Inhibition of Cell Proliferation or Growth of Bladder Urothelial Cancer Cells

Cell growth is an essential requirement for cell cycle progression, but cell cycle arrest may inhibit growth [35]. In the present study, we found that $\mathrm{NaB}$ could significantly reduce the expression of CDK1 (0.5-fold) in HT1376 cells (Figure 4A) and arrest cells at the G2/M 
phase (31\%), relative to the cells without $\mathrm{NaB}$ treatment (9\%) (Figure 4B). In addition, we used the BrdU incorporation assay to evaluate the proliferation of attached HT1376 cells under $\mathrm{NaB}$ treatment. $\mathrm{NaB}$ treatment not only significantly reduced cell growth (Figure $5 \mathrm{~A}$ ) but also blunted the BrdU incorporation rate in HT1376 cells (Figure 5B). Similarly, cell growth was decelerated when the cell culture medium contained the conditioned medium of B. pullicaecorum cultivation. At Day 6 in Figure 5C, the cell growth slowed down from 2.0- to 1.2 -fold $(p<0.01)$ when the medium contained only $5 \%$ conditioned medium, whereas cell growth was significantly reduced to 0.8 -fold when it contained $10 \%$ conditioned medium $(p<0.001)$.

\section{A}
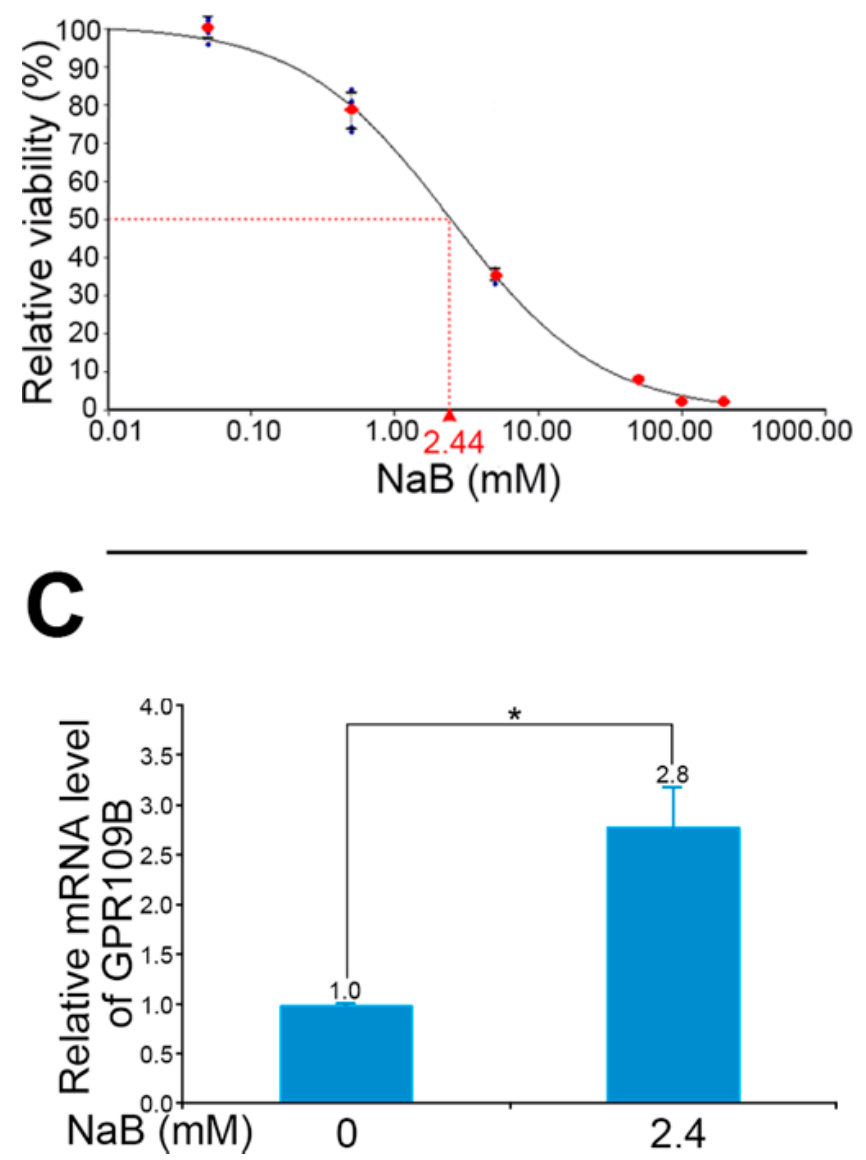

B
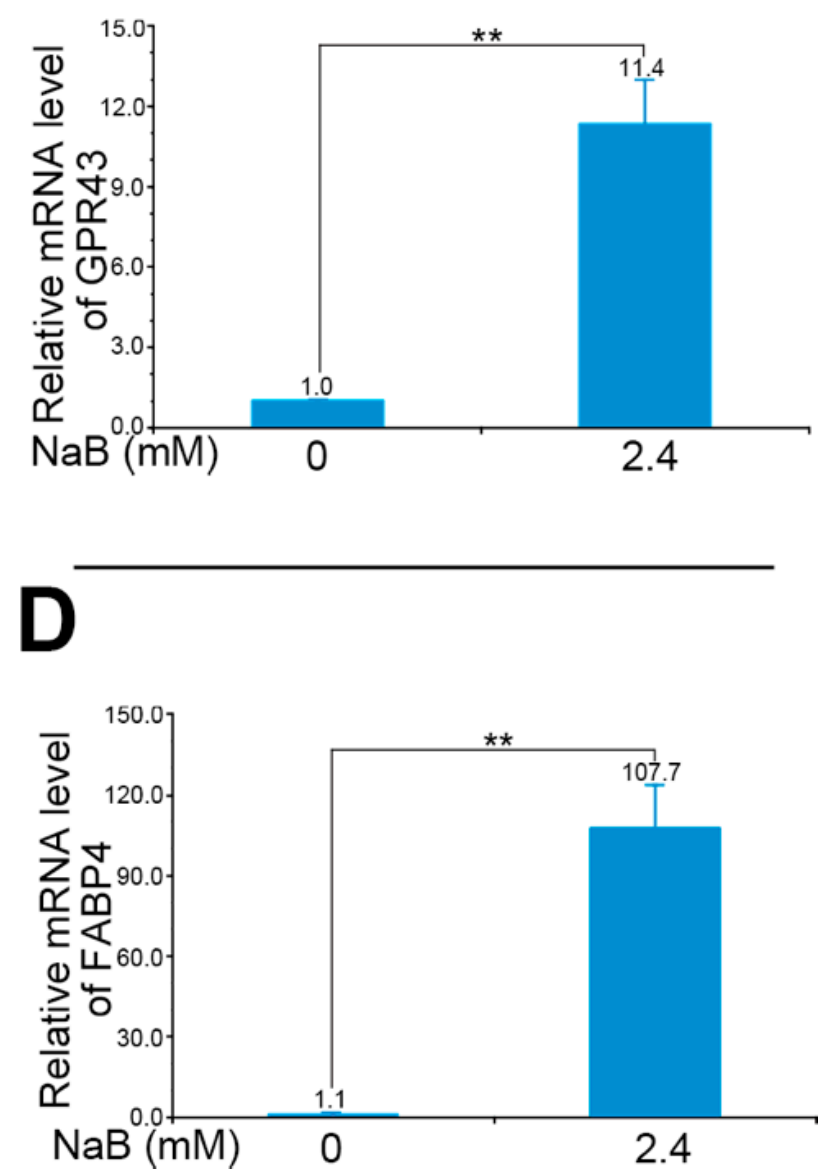

Figure 2. Up-regulation of SCFA-related genes in bladder urothelial cancer cells after NaB treatment. (A) The $\mathrm{IC}_{50}$ value of about $2.4 \mathrm{mM} \mathrm{NaB}$ against HT1376 cells. (B-D) Relative mRNA levels of GPR43, GPR109B, and FABP4 in HT1376 cells. All mRNA levels were adjusted relative to the level of glyceraldehyde-3-phosphate dehydrogenase. Data are the mean \pm SEM of at least two independent experiments. SCFA, short chain fatty acid; NaB, sodium butyrate. ${ }^{*} p<0.05$ and ${ }^{* *} p<0.01$. 


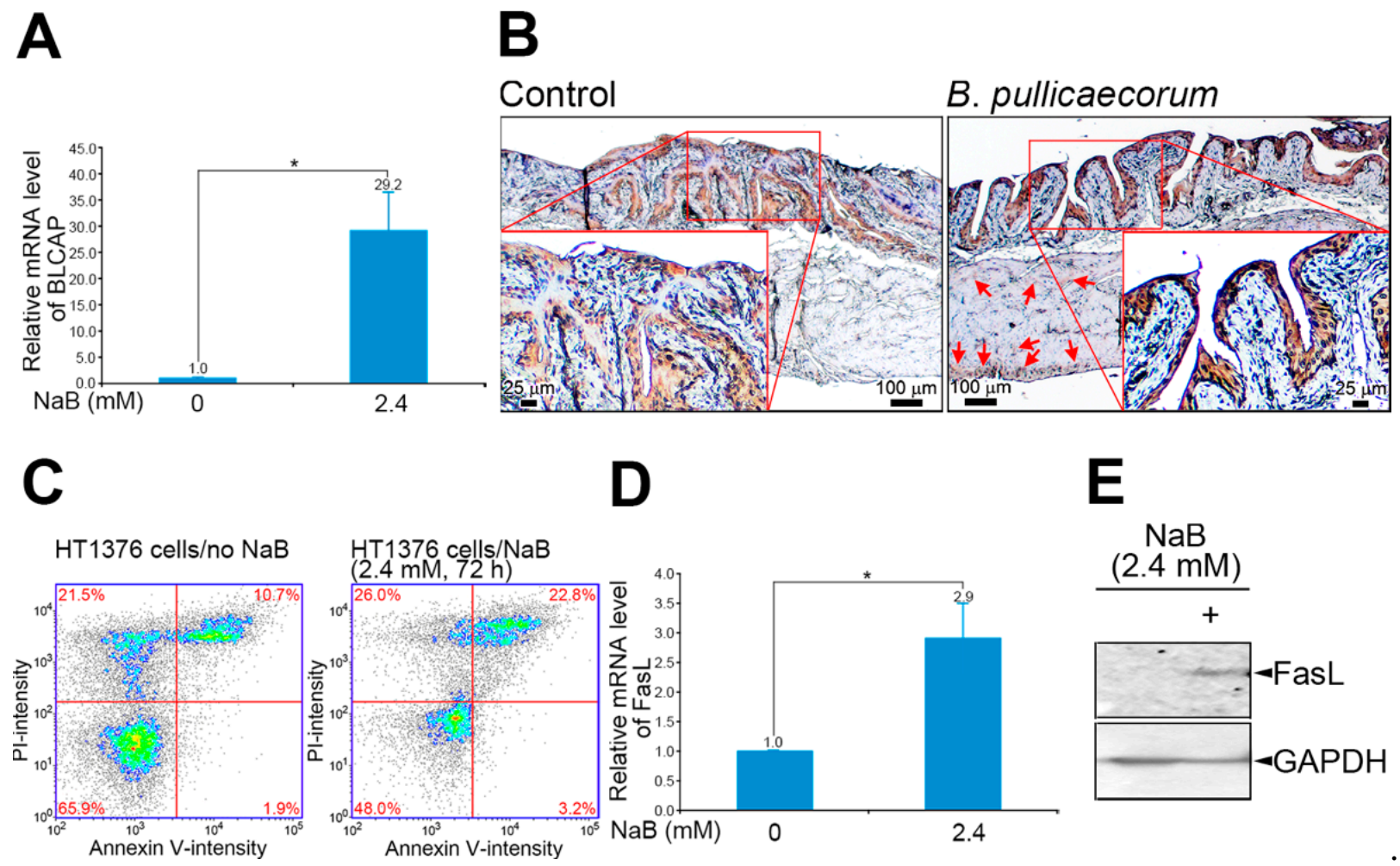

Figure 3. BLCAP and FasL levels in bladder urothelial cells after NaB treatment. (A) Relative mRNA level of BLCAP in HT1376 cells. The mRNA level of BLCAP was adjusted relative to the level of glyceraldehyde-3-phosphate dehydrogenase. (B) Representative images of BLCAP immunohistochemistry staining. Control mice $(n=4)$, without B. pullicaecorum administration; B. pullicaecorum mice $(n=4)$, with $1 \times 10^{7}$ B. pullicaecorum administration through anal injection. (C) Apoptotic rate of HT1376 cells after NaB treatment. (D) Relative mRNA level of FasL in HT1376 cells. The mRNA level of CDK1 was adjusted relative to the level of glyceraldehyde-3-phosphate dehydrogenase. Data are the mean \pm SEM of at least two independent experiments. (E) The protein expression of FasL in HT1376 cells. Data are the mean \pm SEM of at least two independent experiments. $\mathrm{NaB}$, sodium butyrate. ${ }^{*} p<0.05$.

A
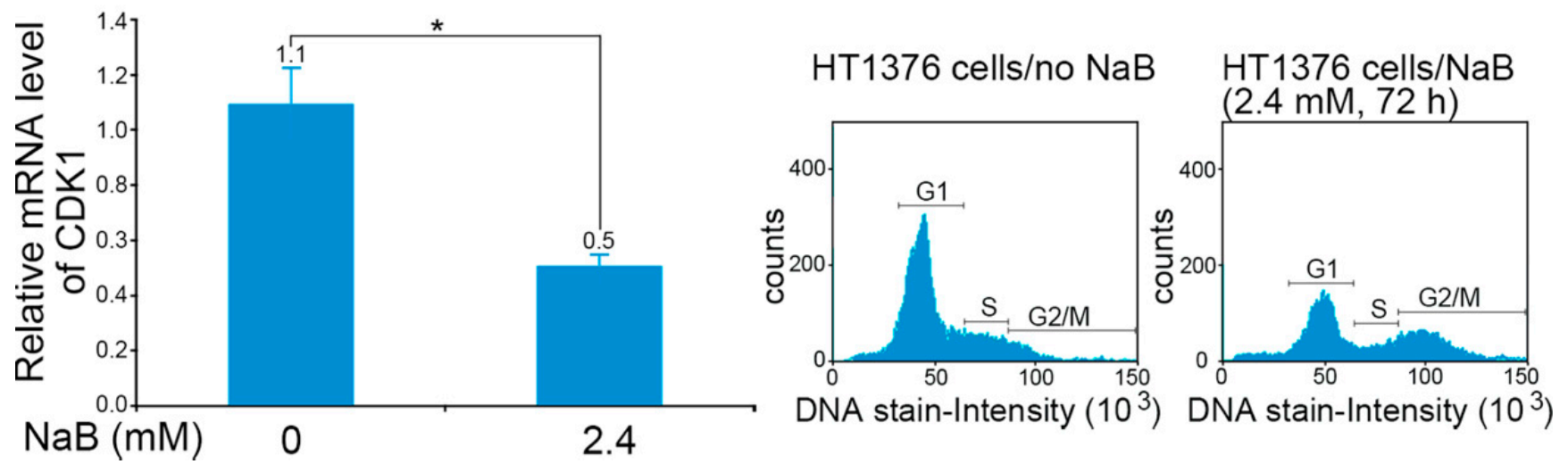

Figure 4. Regulation of cell cycles in bladder urothelial cancer cells by NaB. (A) Relative mRNA level of CDK1 in HT1376 cells. (B) Cell cycle distribution of HT1376 cells after NaB treatment. Data are the mean \pm SEM of at least two independent experiments. $\mathrm{NaB}$, sodium butyrate. ${ }^{*} p<0.05$. 

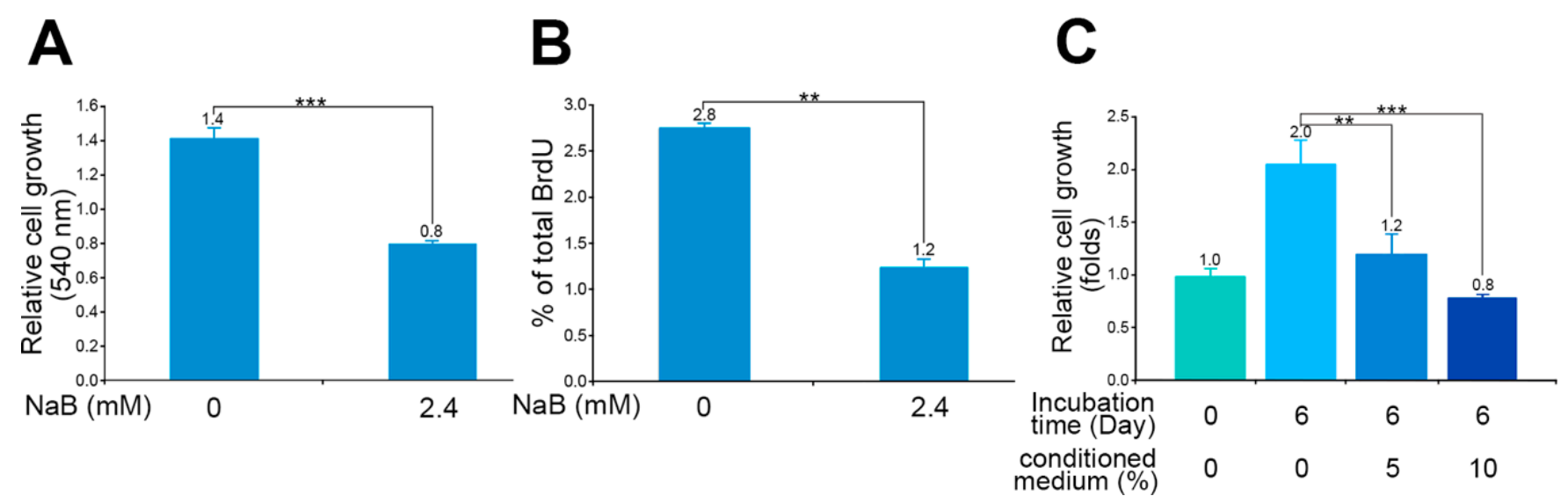

Figure 5. Inhibition of cell growth of bladder urothelial cancer cells by NaB. (A) Relative growth of HT1376 cells after NaB treatment. (B) Change of BrdU incorporation rate in HT1376 cells after NaB treatment. (C) Relative growth of HT1376 cells after conditioned medium treatment. Data are the mean \pm SEM of at least two independent experiments. NaB, sodium butyrate. ${ }^{* *} p<0.01$ and ${ }^{* * *} p<0.001$.

\section{Discussion}

The causes of bladder cancer are becoming increasingly complex and diverse. Urothelial carcinoma is the most common histologic subtype of bladder cancer and accounts for more than $90 \%$ of cases [36]. Epidemiological studies have identified that tobacco, hair dye, and occupational chemical exposure are believed to be responsible for urothelial carcinoma [37-39]. In addition to carcinoma, ketamine-associated ulcerative cystitis is another emerging bladder disease in some countries [40-42]. Therefore, it is of clinical significance whether there are substances that can prevent bladder cells from being threatened by bladder diseases. Here, we found that butyrate could modulate the growth of bladder urothelial cells and promote apoptosis. A supplementation of butyrate-producing B. pullicaecorum might improve the health of the urothelial bladder cells.

It is well-known that changes in the gut microbiota can mediate or modify the effects of environmental factors on the risk of CRC [43]. First, gut microbiota have been shown to play a role in promoting or developing CRC initiation $[44,45]$. For example, Fusobacterium nucleatum may affect carcinogenesis and extend to facilitating resistance to chemotherapy [46]. Second, there are potential benefits to using probiotics and prebiotics to modulate the host inflammatory response, as well as its application in CRC prevention and treatment $[47,48]$. For example, B. pullicaecorum is able to reduce CRC progression [23]. Butyrate is one of the SCFAs that are synthesized from dietary carbohydrates by bacterial fermentation in the colon [19]. Most SCFAs can be absorbed from the colonic lumen and used by colonic epithelial cells, while the remainder are transferred to circulation in different percentages [49-51]. This implies that butyrate in circulation can directly or indirectly function in various peripheral tissues [52] and this is interesting in terms of understanding the effects of butyrate on tissues other than the colon. Our present results are consistent with these reports. We showed that enough B. pullicaecorum in the colon affects the transitional epithelium of the urinary bladder to overexpress two receptors (GPR43 and GPR109B) and one transporter (FABP4).

With properties of anti-inflammation and being a histone deacetylase inhibitor, butyrate enhances barrier function and mucosal immunity in the colon through upregulation of the expression of SCFA receptors and transporters [23,53-55]. In this study, the increased expression of GPR43, GPR109B, and FABP4 was even detected in the transitional epithelium of the urinary bladder of mice treated with B. pullicaecorum. These molecular changes may contribute to the promotion and achievement of optimal bladder health. GPR43 and GPR109B are two SCFA-sensing G protein-coupled receptors, while GPR43 is a fatty acid receptor and GPR109B is a hydroxycarboxylic acid receptor [56]. Briefly, GPR43 is 
known to be activated by SCFAs and may improve anti-inflammatory activity in various tissues [57-59]. Here, we further showed that the transitional epithelium of urinary bladder of mice treated with B. pullicaecorum exhibited increased GPR43 synthesis, which was confirmed by the result of increased gene expression of GPR43 in NaB-treated HT1376 cells. Moreover, these SCFA receptors or transporters were also found to be upregulated in 5637 cells, which were also the bladder urothelial cancer cells (Supplementary Materials Figure S3). This implies that butyrate may increase the expression level of GPR43, GPR109B, and FABP4 in urothelial bladder cells. Butyrate also changed the ability of urothelial bladder cells to respond to the microenvironment.

Not only did we find an increase in GPR43 due to butyrate but perhaps more significantly we also found that the expression of GPR109B and FABP4 showed a similar expression pattern. The molecular effect of butyrate on GPR109B and FABP4 expression is different in different tissues. For example, GPR109B in gut epithelial cells has no expression difference between cancer and normal colon cells [60]. Nevertheless, breast cancer cells have higher GPR109B levels than do non-tumor control cells [61]. However, to our knowledge, this is the first study to determine the expression level of GPR109B in urothelial bladder cells due to butyrate treatment or B. pullicaecorum administration. GPR109B has been specifically identified as a receptor for the inhibition of lipolysis [62-65]. As reviewed by Zaidi et al., fatty acids acquired by lipolysis will nourish cancer cells [66]. Additionally, it has been found that tumor load positively correlates with intracellular lipolysis $[67,68]$. This increased lipolysis may attenuate the therapeutic advantage of human cancers [66,69]. Thus, Li et al. suggested that avoiding excessive lipolysis can be a new therapeutic strategy for cancer treatment [69]. Our data reveal that $\mathrm{NaB}$ treatment or B. pullicaecorum administration may increase GPR109B synthesis to protect bladder urothelial cells.

It has been confirmed in many studies that FABP4 is functionally responsible for aggressive patterns of colon cancer [70], breast cancer [71], ovarian cancer [72], prostate cancer [73], and non-small-cell lung cancer [74]. On the other hand, as reported by Zhong et al., the overexpression of FABP4 is able to repress tumor growth and invasion in hepatocellular carcinoma [75]. This result is consistent with the report of Chiu et al., who suggest that low-grade urothelial bladder cancer has higher FABP4 expression than high-grade cancers [76]. We found that the supplementation of B. pullicaecorum or butyrate treatment increased FABP4 synthesis in urothelial bladder cells, as reported by Mathis et al. [77]. Induction of FABP4 expression may prevent tumor progression. At the same time, we observed increased BLCAP in urothelial bladder cells, not only in the HT1376 cells but also in the 5637 cells (Supplementary Materials Figure S4). BLCAP exhibits a tumor suppressor function in various tumors, including urothelial cancer of the bladder [31] and can reduce cell growth by stimulating apoptosis [32]. The increase in BLCAP by B. pullicaecorum administration and butyrate treatment may reflect cell cycle arrest, FasL expression, and growth inhibition in NaB-treated bladder urothelial cancer cells.

Although we demonstrated that B. pullicaecorum supplementation changes the gene expression profile associated with the butyrate-regulated anticancer effect on bladder urothelial cancer, there are limitations to this study that should be noted. First, the possible effect of whole metabolites derived from B. pullicaecorum on bladder cancer was not fully evaluated, especially in combination with other anticancer drugs. For example, Maruyama et al. also showed that butyrate administration strengthens the anti-cancer effect of cisplatin, which is a standard chemotherapy for advanced bladder cancer [78]. Second, the potential interaction of the probiotic B. pullicaecorum with other gut microbiota and their effect on the efficacy of anti-cancer therapy was not addressed in this study. For instance, Aso and Akazan reported that oral administration of probiotics decreases superficial bladder cancer recurrence [18]. Manipulating gut microbiota, is also emerging as a promising adjuvant treatment to enhance the therapeutic effect of cancer immunotherapy $[79,80]$. Taken together, the therapeutic effect of B. pullicaecorum supplementation on the efficacy of anticancer drugs in bladder urothelial cancers warrants future studies. 


\section{Conclusions}

SCFAs, such as butyrate, that are produced by gut microbial metabolism is commomly studied in colon diseases. In this study, we demonstrated that butyrate derived from B. pullicaecorum supplementation changes gene expression in bladder urothelial cancer cells in vitro. The butyrate-responsive molecular signatures correlate with the cellular growth of bladder urothelial cancer cells. Our results suggest that butyrate-producing probiotics, such as B. pullicaecorum, mediate the anticancer effect on bladder urothelial cells by increasing the anti-inflammation activity and anti-oncogenic potential of bladder urothelial cells.

Supplementary Materials: The following are available online at https:/ /www.mdpi.com/article/10 .3390/diagnostics11122270/s1-s4, Figure S1: Timing of B. pullicaecorum administration. Figure S2: Relative level of B. pullicaecorum in mouse stool. Figure S3: Relative mRNA level of butyrate-effected genes in 5637 cells. Figure S4: Relative mRNA level of BLCAP in 5637 cells.

Author Contributions: Y.-C.W., W.-C.K., C.-Y.L., K.-W.C., Y.-C.C., C.-C.C., and C.-J.H. designed the experiments and analyzed the data. Y.-C.W., W.-C.K., C.-Y.L., and C.-J.H. performed the experiments and wrote the paper. All authors have read and agreed to the published version of the manuscript.

Funding: This work was supported by funds from Cathay General Hospital (No. CGH-2020 to Clinical Cancer Genetics Laboratory, C.-J.H.).

Institutional Review Board Statement: The study was conducted according to the guidelines of the Institutional Animal Care and Use Committee (IACUC) in Cathay General Hospital (IACUC No. CGH-IACUC-106-003).

Informed Consent Statement: Not applicable.

Data Availability Statement: The raw data supporting the conclusions of this article will be made available by the authors without undue reservation.

Conflicts of Interest: The authors declare no conflict of interest.

\section{References}

1. Dy, G.W.; Gore, J.L.; Forouzanfar, M.H.; Naghavi, M.; Fitzmaurice, C. Global Burden of Urologic Cancers, 1990-2013. Eur. Urol. 2017, 71, 437-446. [CrossRef] [PubMed]

2. Bosetti, C.; Bertuccio, P.; Chatenoud, L.; Negri, E.; La Vecchia, C.; Levi, F. Trends in mortality from urologic cancers in Europe, 1970-2008. Eur. Urol. 2011, 60, 1-15. [CrossRef]

3. Sanli, O.; Dobruch, J.; Knowles, M.A.; Burger, M.; Alemozaffar, M.; Nielsen, M.E.; Lotan, Y. Bladder cancer. Nat. Rev. Dis. Primers 2017, 3, 17022. [CrossRef] [PubMed]

4. Willis, D.; Kamat, A.M. Nonurothelial bladder cancer and rare variant histologies. Hematol. Oncol. Clin. North. Am. 2015, 29, 237-252. [CrossRef]

5. Guo, C.C.; Czerniak, B. Bladder Cancer in the Genomic Era. Arch. Pathol. Lab. Med. 2019, 143, 695-704. [CrossRef]

6. Mansour, B.; Monyok, A.; Makra, N.; Gajdacs, M.; Vadnay, I.; Ligeti, B.; Juhasz, J.; Szabo, D.; Ostorhazi, E. Bladder cancer-related microbiota: Examining differences in urine and tissue samples. Sci. Rep. 2020, 10, 11042. [CrossRef]

7. Bucevic Popovic, V.; Situm, M.; Chow, C.T.; Chan, L.S.; Roje, B.; Terzic, J. The urinary microbiome associated with bladder cancer. Sci. Rep. 2018, 8, 12157. [CrossRef] [PubMed]

8. Wu, P.; Zhang, G.; Zhao, J.; Chen, J.; Chen, Y.; Huang, W.; Zhong, J.; Zeng, J. Profiling the Urinary Microbiota in Male Patients with Bladder Cancer in China. Front. Cell. Infect. Microbiol. 2018, 8, 167. [CrossRef]

9. Bi, H.; Tian, Y.; Song, C.; Li, J.; Liu, T.; Chen, Z.; Chen, C.; Huang, Y.; Zhang, Y. Urinary microbiota-A potential biomarker and therapeutic target for bladder cancer. J. Med. Microbiol. 2019, 68, 1471-1478. [CrossRef]

10. Bajic, P.; Wolfe, A.J.; Gupta, G.N. The Urinary Microbiome: Implications in Bladder Cancer Pathogenesis and Therapeutics. Urology 2019, 126, 10-15. [CrossRef]

11. Enaud, R.; Prevel, R.; Ciarlo, E.; Beaufils, F.; Wieers, G.; Guery, B.; Delhaes, L. The Gut-Lung Axis in Health and Respiratory Diseases: A Place for Inter-Organ and Inter-Kingdom Crosstalks. Front. Cell. Infect. Microbiol. 2020, 10, 9. [CrossRef]

12. Fernandez, M.F; Reina-Perez, I.; Astorga, J.M.; Rodriguez-Carrillo, A.; Plaza-Diaz, J.; Fontana, L. Breast Cancer and Its Relationship with the Microbiota. Int. J. Environ. Res. Public Health 2018, 15, 1747. [CrossRef]

13. Human Microbiome Project, C. Structure, function and diversity of the healthy human microbiome. Nature 2012, 486, 207-214. [CrossRef]

14. Klement, R.J.; Pazienza, V. Impact of Different Types of Diet on Gut Microbiota Profiles and Cancer Prevention and Treatment. Medicina 2019, 55, 84. [CrossRef] 
15. He, C.; Li, B.; Huang, L.; Teng, C.; Bao, Y.; Ren, M.; Shan, Y. Gut microbial composition changes in bladder cancer patients: A case-control study in Harbin, China. Asia. Pac. J. Clin. Nutr. 2020, 29, 395-403. [CrossRef]

16. He, C.; Huang, L.; Lei, P.; Liu, X.; Li, B.; Shan, Y. Sulforaphane Normalizes Intestinal Flora and Enhances Gut Barrier in Mice with BBN-Induced Bladder Cancer. Mol. Nutr. Food Res. 2018, 62, e1800427. [CrossRef]

17. Vivarelli, S.; Falzone, L.; Leonardi, G.C.; Salmeri, M.; Libra, M. Novel insights on gut microbiota manipulation and immune checkpoint inhibition in cancer (Review). Int. J. Oncol. 2021, 59, 75-91. [CrossRef]

18. Aso, Y.; Akazan, H. Prophylactic effect of a Lactobacillus casei preparation on the recurrence of superficial bladder cancer. BLP Study Group. Urol. Int. 1992, 49, 125-129. [CrossRef]

19. Wong, J.M.; Jenkins, D.J. Carbohydrate digestibility and metabolic effects. J. Nutr. 2007, 137, 2539S-2546S. [CrossRef]

20. Dyer, J.P.; Featherstone, J.M.; Solomon, L.Z.; Crook, T.J.; Cooper, A.J.; Malone, P.S. The effect of short-chain fatty acids butyrate, propionate, and acetate on urothelial cell kinetics in vitro: Potential therapy in augmentation cystoplasty. Pediatr. Surg. Int. 2005, 21, 521-526. [CrossRef]

21. Aljabery, F.; Shabo, I.; Gimm, O.; Jahnson, S.; Olsson, H. The expression profile of p14, p53 and p21 in tumour cells is associated with disease-specific survival and the outcome of postoperative chemotherapy treatment in muscle-invasive bladder cancer. Urol. Oncol. 2018, 36, 530.e537-530.e518. [CrossRef]

22. Boesmans, L.; Valles-Colomer, M.; Wang, J.; Eeckhaut, V.; Falony, G.; Ducatelle, R.; Van Immerseel, F.; Raes, J.; Verbeke, K. Butyrate Producers as Potential Next-Generation Probiotics: Safety Assessment of the Administration of Butyricicoccus pullicaecorum to Healthy Volunteers. mSystems 2018, 3, e00094-18. [CrossRef]

23. Chang, S.C.; Shen, M.H.; Liu, C.Y.; Pu, C.M.; Hu, J.M.; Huang, C.J. A gut butyrate-producing bacterium Butyricicoccus pullicaecorum regulates short-chain fatty acid transporter and receptor to reduce the progression of 1,2-dimethylhydrazineassociated colorectal cancer. Oncol. Lett. 2020, 20, 327. [CrossRef]

24. Livak, K.J.; Schmittgen, T.D. Analysis of relative gene expression data using real-time quantitative PCR and the 2(-Delta Delta C(T)) Method. Methods 2001, 25, 402-408. [CrossRef]

25. Wu, J.T.; Lin, C.L.; Huang, C.J.; Cheng, Y.C.; Chien, C.C.; Sung, Y.C. Potential synergistic effects of sorafenib and CP-31398 for treating anaplastic thyroid cancer with p53 mutations. Oncol. Lett. 2020, 19, 3021-3026. [CrossRef]

26. Tang, Q.; Wang, Y.; Huang, R.; You, Q.; Wang, G.; Chen, Y.; Jiang, Z.; Liu, Z.; Yu, L.; Muhammad, S.; et al. Preparation of anti-tumor nanoparticle and its inhibition to peritoneal dissemination of colon cancer. PLoS ONE 2014, 9, e98455. [CrossRef]

27. Beberok, A.; Rzepka, Z.; Respondek, M.; Rok, J.; Stradowski, M.; Wrzesniok, D. Moxifloxacin as an inducer of apoptosis in melanoma cells: A study at the cellular and molecular level. Toxicol. Vitro 2019, 55, 75-92. [CrossRef]

28. Rok, J.; Rzepka, Z.; Beberok, A.; Pawlik, J.; Wrzesniok, D. Cellular and Molecular Aspects of Anti-Melanoma Effect of MinocyclineA Study of Cytotoxicity and Apoptosis on Human Melanotic Melanoma Cells. Int. J. Mol. Sci. 2020, 21, 6917. [CrossRef]

29. Chen, S.K.; Chung, C.A.; Cheng, Y.C.; Huang, C.J.; Ruaan, R.C.; Chen, W.Y.; Li, C.; Tsao, C.W.; Hu, W.W.; Chien, C.C. Hydrostatic pressure enhances mitomycin $C$ induced apoptosis in urothelial carcinoma cells. Urol. Oncol. 2014, 32, 26.e17-26.e24. [CrossRef]

30. Wu, X.; Wu, Y.; He, L.; Wu, L.; Wang, X.; Liu, Z. Effects of the intestinal microbial metabolite butyrate on the development of colorectal cancer. J. Cancer 2018, 9, 2510-2517. [CrossRef]

31. Huang, Y.T.; Wu, T.S.; Lu, C.C.; Yu, F.Y.; Liu, B.H. Aristolochic acid I interferes with the expression of BLCAP tumor suppressor gene in human cells. Toxicol. Lett. 2018, 291, 129-137. [CrossRef]

32. Wu, L.; He, S.; He, Y.; Wang, X.; Lu, L. IC-2 Suppresses Proliferation and Induces Apoptosis of Bladder Cancer Cells via the Wnt/beta-Catenin Pathway. Med. Sci. Monit. 2018, 24, 8074-8080. [CrossRef]

33. Rieger, A.M.; Nelson, K.L.; Konowalchuk, J.D.; Barreda, D.R. Modified annexin V/propidium iodide apoptosis assay for accurate assessment of cell death. J. Vis. Exp. 2011, 50, e2597. [CrossRef]

34. Volpe, E.; Sambucci, M.; Battistini, L.; Borsellino, G. Fas-Fas Ligand: Checkpoint of T Cell Functions in Multiple Sclerosis. Front. Immunol. 2016, 7, 382. [CrossRef]

35. Goranov, A.I.; Cook, M.; Ricicova, M.; Ben-Ari, G.; Gonzalez, C.; Hansen, C.; Tyers, M.; Amon, A. The rate of cell growth is governed by cell cycle stage. Genes Dev. 2009, 23, 1408-1422. [CrossRef]

36. Gupta, P.; Jain, M.; Kapoor, R.; Muruganandham, K.; Srivastava, A.; Mandhani, A. Impact of age and gender on the clinicopathological characteristics of bladder cancer. Indian J. Urol. 2009, 25, 207-210. [CrossRef]

37. Cumberbatch, M.G.K.; Noon, A.P. Epidemiology, aetiology and screening of bladder cancer. Transl. Androl. Urol. 2019,8 , 5-11. [CrossRef]

38. Cumberbatch, M.G.K.; Jubber, I.; Black, P.C.; Esperto, F.; Figueroa, J.D.; Kamat, A.M.; Kiemeney, L.; Lotan, Y.; Pang, K.; Silverman, D.T.; et al. Epidemiology of Bladder Cancer: A Systematic Review and Contemporary Update of Risk Factors in 2018. Eur. Urol. 2018, 74, 784-795. [CrossRef]

39. Andrew, A.S.; Schned, A.R.; Heaney, J.A.; Karagas, M.R. Bladder cancer risk and personal hair dye use. Int. J. Cancer 2004, 109, 581-586. [CrossRef]

40. Orhurhu, V.J.; Vashisht, R.; Claus, L.E.; Cohen, S.P. Ketamine Toxicity; StatPearls: Treasure Island, FL, USA, 2021.

41. Huang, C.J.; Lee, F.K.; Chen, S.K.; Chien, C.C.; Wu, S.T.; Wang, Y.C. Clinical significance of interleukin6 and inducible nitric oxide synthase in ketamineinduced cystitis. Int. J. Mol. Med. 2018, 41, 836-844. [CrossRef]

42. Castellani, D.; Pirola, G.M.; Gubbiotti, M.; Rubilotta, E.; Gudaru, K.; Gregori, A.; Dellabella, M. What urologists need to know about ketamine-induced uropathy: A systematic review. Neurourol. Urodyn. 2020, 39, 1049-1062. [CrossRef] [PubMed] 
43. Song, M.; Chan, A.T.; Sun, J. Influence of the Gut Microbiome, Diet, and Environment on Risk of Colorectal Cancer. Gastroenterology 2020, 158, 322-340. [CrossRef] [PubMed]

44. Perillo, F.; Amoroso, C.; Strati, F.; Giuffre, M.R.; Diaz-Basabe, A.; Lattanzi, G.; Facciotti, F. Gut Microbiota Manipulation as a Tool for Colorectal Cancer Management: Recent Advances in Its Use for Therapeutic Purposes. Int. J. Mol. Sci. 2020, 21, 5389. [CrossRef] [PubMed]

45. Gao, R.; Gao, Z.; Huang, L.; Qin, H. Gut microbiota and colorectal cancer. Eur. J. Clin. Microbiol. Infect. Dis. 2017, 36, 757-769. [CrossRef]

46. Garrett, W.S. The gut microbiota and colon cancer. Science 2019, 364, 1133-1135. [CrossRef]

47. Fong, W.; Li, Q.; Yu, J. Gut microbiota modulation: A novel strategy for prevention and treatment of colorectal cancer. Oncogene 2020, 39, 4925-4943. [CrossRef]

48. De Almeida, C.V.; de Camargo, M.R.; Russo, E.; Amedei, A. Role of diet and gut microbiota on colorectal cancer immunomodulation. World J. Gastroenterol. 2019, 25, 151-162. [CrossRef]

49. Liu, J.L.; Segovia, I.; Yuan, X.L.; Gao, Z.H. Controversial Roles of Gut Microbiota-Derived Short-Chain Fatty Acids (SCFAs) on Pancreatic beta-Cell Growth and Insulin Secretion. Int. J. Mol. Sci. 2020, 21, 910. [CrossRef]

50. Iraporda, C.; Errea, A.; Romanin, D.E.; Cayet, D.; Pereyra, E.; Pignataro, O.; Sirard, J.C.; Garrote, G.L.; Abraham, A.G.; Rumbo, M. Lactate and short chain fatty acids produced by microbial fermentation downregulate proinflammatory responses in intestinal epithelial cells and myeloid cells. Immunobiology 2015, 220, 1161-1169. [CrossRef]

51. Hijova, E.; Chmelarova, A. Short chain fatty acids and colonic health. Bratisl. Lek. Listy 2007, 108, 354-358.

52. McNabney, S.M.; Henagan, T.M. Short Chain Fatty Acids in the Colon and Peripheral Tissues: A Focus on Butyrate, Colon Cancer, Obesity and Insulin Resistance. Nutrients 2017, 9, 1348. [CrossRef]

53. Zimmerman, M.A.; Singh, N.; Martin, P.M.; Thangaraju, M.; Ganapathy, V.; Waller, J.L.; Shi, H.; Robertson, K.D.; Munn, D.H.; Liu, K. Butyrate suppresses colonic inflammation through HDAC1-dependent Fas upregulation and Fas-mediated apoptosis of T cells. Am. J. Physiol. Gastrointest. Liver Physiol. 2012, 302, G1405-G1415. [CrossRef] [PubMed]

54. Stilling, R.M.; van de Wouw, M.; Clarke, G.; Stanton, C.; Dinan, T.G.; Cryan, J.F. The neuropharmacology of butyrate: The bread and butter of the microbiota-gut-brain axis? Neurochem. Int. 2016, 99, 110-132. [CrossRef] [PubMed]

55. Liu, H.; Wang, J.; He, T.; Becker, S.; Zhang, G.; Li, D.; Ma, X. Butyrate: A Double-Edged Sword for Health? Adv. Nutr. 2018, 9 , 21-29. [CrossRef] [PubMed]

56. Cosin-Roger, J.; Ortiz-Masia, D.; Barrachina, M.D.; Calatayud, S. Metabolite Sensing GPCRs: Promising Therapeutic Targets for Cancer Treatment? Cells 2020, 9, 2345. [CrossRef]

57. Zhang, C.; Chang, J.; Wu, W.; Deng, Y.; Zhou, P.; Jiang, W.; Wang, C.; Huang, F. Activation of GPR43 suppresses TNF-alphainduced inflammatory response in human fibroblast-like synoviocytes. Arch. Biochem. Biophys. 2020, 684, 108297. [CrossRef]

58. Nakajima, A.; Nakatani, A.; Hasegawa, S.; Irie, J.; Ozawa, K.; Tsujimoto, G.; Suganami, T.; Itoh, H.; Kimura, I. The short chain fatty acid receptor GPR43 regulates inflammatory signals in adipose tissue M2-type macrophages. PLoS ONE 2017, 12, e0179696. [CrossRef]

59. Sivaprakasam, S.; Gurav, A.; Paschall, A.V.; Coe, G.L.; Chaudhary, K.; Cai, Y.; Kolhe, R.; Martin, P.; Browning, D.; Huang, L.; et al. An essential role of Ffar2 (Gpr43) in dietary fibre-mediated promotion of healthy composition of gut microbiota and suppression of intestinal carcinogenesis. Oncogenesis 2016, 5, e238. [CrossRef]

60. Thangaraju, M.; Cresci, G.A.; Liu, K.; Ananth, S.; Gnanaprakasam, J.P.; Browning, D.D.; Mellinger, J.D.; Smith, S.B.; Digby, G.J.; Lambert, N.A.; et al. GPR109A is a G-protein-coupled receptor for the bacterial fermentation product butyrate and functions as a tumor suppressor in colon. Cancer Res. 2009, 69, 2826-2832. [CrossRef]

61. Staubert, C.; Broom, O.J.; Nordstrom, A. Hydroxycarboxylic acid receptors are essential for breast cancer cells to control their lipid/fatty acid metabolism. Oncotarget 2015, 6, 19706-19720. [CrossRef]

62. Ahmed, K.; Tunaru, S.; Langhans, C.D.; Hanson, J.; Michalski, C.W.; Kolker, S.; Jones, P.M.; Okun, J.G.; Offermanns, S. Deorphanization of GPR109B as a receptor for the beta-oxidation intermediate 3-OH-octanoic acid and its role in the regulation of lipolysis. J. Biol. Chem. 2009, 284, 21928-21933. [CrossRef]

63. Skinner, P.J.; Webb, P.J.; Sage, C.R.; Dang, T.H.; Pride, C.C.; Chen, R.; Tamura, S.Y.; Richman, J.G.; Connolly, D.T.; Semple, G. 5-N, N-Disubstituted 5-aminopyrazole-3-carboxylic acids are highly potent agonists of GPR109b. Bioorg. Med. Chem. Lett. 2009, 19, 4207-4209. [CrossRef]

64. Skinner, P.J.; Cherrier, M.C.; Webb, P.J.; Sage, C.R.; Dang, H.T.; Pride, C.C.; Chen, R.; Tamura, S.Y.; Richman, J.G.; Connolly, D.T.; et al. 3-Nitro-4-amino benzoic acids and 6-amino nicotinic acids are highly selective agonists of GPR109b. Bioorg. Med. Chem. Lett. 2007, 17, 6619-6622. [CrossRef] [PubMed]

65. Semple, G.; Skinner, P.J.; Cherrier, M.C.; Webb, P.J.; Sage, C.R.; Tamura, S.Y.; Chen, R.; Richman, J.G.; Connolly, D.T. 1-Alkylbenzotriazole-5-carboxylic acids are highly selective agonists of the human orphan G-protein-coupled receptor GPR109b. J. Med. Chem. 2006, 49, 1227-1230. [CrossRef]

66. Zaidi, N.; Lupien, L.; Kuemmerle, N.B.; Kinlaw, W.B.; Swinnen, J.V.; Smans, K. Lipogenesis and lipolysis: The pathways exploited by the cancer cells to acquire fatty acids. Prog. Lipid Res. 2013, 52, 585-589. [CrossRef]

67. Sagar, G.; Sah, R.P.; Javeed, N.; Dutta, S.K.; Smyrk, T.C.; Lau, J.S.; Giorgadze, N.; Tchkonia, T.; Kirkland, J.L.; Chari, S.T.; et al. Pathogenesis of pancreatic cancer exosome-induced lipolysis in adipose tissue. Gut 2016, 65, 1165-1174. [CrossRef] [PubMed]

68. Santos, C.R.; Schulze, A. Lipid metabolism in cancer. FEBS J. 2012, 279, 2610-2623. [CrossRef] 
69. Li, J.; Zhao, S.; Zhou, X.; Zhang, T.; Zhao, L.; Miao, P.; Song, S.; Sun, X.; Liu, J.; Zhao, X.; et al. Inhibition of lipolysis by mercaptoacetate and etomoxir specifically sensitize drug-resistant lung adenocarcinoma cell to paclitaxel. PLoS ONE 2013, 8, e74623. [CrossRef] [PubMed]

70. Tian, W.; Zhang, W.; Zhang, Y.; Zhu, T.; Hua, Y.; Li, H.; Zhang, Q.; Xia, M. FABP4 promotes invasion and metastasis of colon cancer by regulating fatty acid transport. Cancer Cell Int. 2020, 20, 512. [CrossRef]

71. Guaita-Esteruelas, S.; Bosquet, A.; Saavedra, P.; Guma, J.; Girona, J.; Lam, E.W.; Amillano, K.; Borras, J.; Masana, L. Exogenous FABP4 increases breast cancer cell proliferation and activates the expression of fatty acid transport proteins. Mol. Carcinog. 2017, 56, 208-217. [CrossRef]

72. Gharpure, K.M.; Pradeep, S.; Sans, M.; Rupaimoole, R.; Ivan, C.; Wu, S.Y.; Bayraktar, E.; Nagaraja, A.S.; Mangala, L.S.; Zhang, X.; et al. FABP4 as a key determinant of metastatic potential of ovarian cancer. Nat. Commun. 2018, 9, 2923. [CrossRef] [PubMed]

73. Herroon, M.K.; Rajagurubandara, E.; Hardaway, A.L.; Powell, K.; Turchick, A.; Feldmann, D.; Podgorski, I. Bone marrow adipocytes promote tumor growth in bone via FABP4-dependent mechanisms. Oncotarget 2013, 4, 2108-2123. [CrossRef]

74. Tang, Z.; Shen, Q.; Xie, H.; Zhou, X.; Li, J.; Feng, J.; Liu, H.; Wang, W.; Zhang, S.; Ni, S. Elevated expression of FABP3 and FABP4 cooperatively correlates with poor prognosis in non-small cell lung cancer (NSCLC). Oncotarget 2016, 7, 46253-46262. [CrossRef]

75. Zhong, C.Q.; Zhang, X.P.; Ma, N.; Zhang, E.B.; Li, J.J.; Jiang, Y.B.; Gao, Y.Z.; Yuan, Y.M.; Lan, S.Q.; Xie, D.; et al. FABP4 suppresses proliferation and invasion of hepatocellular carcinoma cells and predicts a poor prognosis for hepatocellular carcinoma. Cancer Med. 2018, 7, 2629-2640. [CrossRef]

76. Chiu, M.; McBeth, L.; Sindhwani, P.; Hinds, T.D. Deciphering the Roles of Thiazolidinediones and PPARgamma in Bladder Cancer. PPAR Res. 2017, 2017, 4810672. [CrossRef]

77. Mathis, C.; Lascombe, I.; Monnien, F.; Bittard, H.; Kleinclauss, F.; Bedgedjian, I.; Fauconnet, S.; Valmary-Degano, S. Downregulation of A-FABP predicts non-muscle invasive bladder cancer progression: Investigation with a long term clinical follow-up. BMC Cancer 2018, 18, 1239. [CrossRef] [PubMed]

78. Maruyama, T.; Yamamoto, S.; Qiu, J.; Ueda, Y.; Suzuki, T.; Nojima, M.; Shima, H. Apoptosis of bladder cancer by sodium butyrate and cisplatin. J. Infect. Chemother. 2012, 18, 288-295. [CrossRef] [PubMed]

79. Matson, V.; Chervin, C.S.; Gajewski, T.F. Cancer and the Microbiome-Influence of the Commensal Microbiota on Cancer, Immune Responses, and Immunotherapy. Gastroenterology 2021, 160, 600-613. [CrossRef] [PubMed]

80. Yi, M.; Jiao, D.; Qin, S.; Chu, Q.; Li, A.; Wu, K. Manipulating Gut Microbiota Composition to Enhance the Therapeutic Effect of Cancer Immunotherapy. Integr. Cancer. Ther. 2019, 18, 1534735419876351. [CrossRef] [PubMed] 